Reviu Akuntansi dan Bisnis Indonesia, Vol. 5 No. 2, Hlm 185-196, Desember 2021

Website: http://journal.umy.ac.id/index.php/rab

\title{
Determinan Efisiensi Investasi dengan Risiko Litigasi sebagai Variabel Moderasi
}

Erni Suryandari Fathmaningrum; Dinda Rintania Dewi

Program Studi Akuntansi Universitas Muhammadiyah Yogyakarta

I N F O A R T I K E L

Kata Kunci:

Kualitas Laporan Keuangan;

Konservatisme; Debt Maturity;

Sustainability Reporting;

Efisiensi Investasi; Risiko

Litigasi

Jenis Artikel:

Penelitian Empiris

Korespondensi:

erni.suryandari34@gmail.com

Proses Artikel:

Diterima 16 Sept 2021

Review 20 Oktober 2021

Revisi 10 Desember 021

Revisi 21 Desember 2021

Diterbitkan Desember 2021

Sitasi:

Fathmaningrum, E.S., \& Dewi,

D.R. (2021). Determinan

Efisiensi Investasi dengan Risiko

Litigasi sebagai Variabel

Moderasi. Reviu Akuntansi dan

Bisnis Indonesia, 5(2), 184-196.

Link Artikel:

10.18196/rabin.v5i2.12748

\section{A B S T R A K}

Latar Belakang:

Pada tahun 2020, BPS menyatakan laju pertumbuhan PDB sektor manufaktur mengalami penuruan sebesar -2,93 dibanding tahun 2019 yaitu sebesar 3,80. Penurunan laju pertumbuhan PDB yang dialami perusahaan sektor manufaktur merupakan dampak dari Covid-19 yang sedang melanda dunia. Penurunan laju pertumbuhan PDB perusahaan sektor manufatur berpengaruh terhadap tingkat efisiensi investasi yang dilakukan perusahaan.

Tujuan:

Penelitian ini memiliki tujuan untuk menguji pengaruh kualitas laporan keuangan, konservatisme, debt maturity dan sustainability reporting terhadap efisiensi investasi dengan risiko litigasi sebagai variable moderasi.

\section{Metode Penelitian:}

Dalam penelitian ini menggunakan teknik analisis data yaitu Regresi Linear Berganda dan Moderated Regression Analysis (MRA).

\section{Hasil Penelitian:}

Hasil penelitian ini menunjukkan bahwa kualitas laporan keuangan, konservatisme, dan debt marurity berpengaruh positif terhadap efisiensi investasi. Sementara sustainability reporting tidak berpengaruh terhadap efisiensi investasi. Hasil penelitian ini juga menunjukkan bahwa risiko litigasi memperkuat pengaruh positif kualitas laporan keuangan dan debt maturity terhadap efisiensi investasi.

\section{Keterbatasan Penelitian:}

Penelitian ini memiliki keterbatasan hanya berfokus pada perusahaan sektor manufaktur saja dan hanya menguji pengaruh kualitas laporan keuangan, konservatisme, debt maturity, dan sustainability reporting terhadap efisiensi investasi

\section{Keaslian/Novetly Penelitian:}

Penelitian ini memiliki pembaharuan yaitu menambahkan risiko litigasi sebagai variabel moderasi. Hal ini dikarenakan hasil penilitian yang tidak konsisten memungkinkan terdapat faktor lain yang mempengaruhi efisiensi investasi. 


\section{PENDAHULUAN}

Menurut Barri (2013) investasi merupkan semua hal yang berkaitan dengan modal yang dikeluarkan oleh perusahaan seperti pengeluaran modal, akuisisi, serta penelitian dan pengembangan. Investasi secara luas adalah keputusan yang diambil perusahaan untuk memanfaatkan modal yang dimiliki dalam rangka membeli aset yang dibutuhkan agar terciptanya keuntungan dimasa mendatang. Efisiensi yaitu kegiatan yang memanfaatkan sumber daya yang dimiliki secara tepat untuk menghindari terjadinya pemborosan. Perusahaan berusahan untuk melakukan kegiatan operasionalnya secara efisien agar tujuan perusahaan dapat tercapai dan mengurangi jumlah biaya yang dikeluarkan. Perusahaan yang memutuskan untuk melakukan investasi harus dijalankan secara efisien. Hal ini dikarenakan agar perusahaan mendapatkan manfaat atas investasi yang dilakukan. Selain itu, keputusan investasi yang diambil perusahaan harus tepat sasaran agar efisiensi dapat tercapai. Jika investasi yang dilakukan perusahaan berjalan secara efisien, hal ini menunjukkan bahwa penggunaan sumber daya perusahaan dilakukan dengan akurat. Efisiensi investasi merupakan jenis investasi yang menguntungkan bagi perusahaan karena merupakan tingkat investasi yang optimal bagi perusahaan.

Pada tahun 2020, Badan Pusat Statistik (BPS) menyatakan bahwa laju pertumbuhan Pusat Domestik Bruto (PDB) perusahaan sektor manufatur mengalami penurunan yaitu hanya tumbuh sebesar -2,93 dibanding tahun 2019 yaitu sebesar 3,80. Penurunan laju pertumbuhan PDB pada perusahaan sektor manufaktur merupakan dampak dari pandemi Covid-19 yang sedang melanda dunia. Pandemi Covid-19 mengakibatkan daya beli masyarakat mengalami penurunan yang mengakibatkan pendapatan perusahaan menurun sehingga berpengaruh terhadap terhadap efisiensi investasi yang dilakukan.

Keputusan untuk melakukan investasi dipilih berdasarkan kondisi perusahaan yang dapat dilihat dari laporan keuangan perusahaan (Ardana \& Sujana, 2018). Kualitas laporan keuangan suatu perusahaan merupakan hal yang utama bagi para stakeholder karena terkait dengan efisiensi investasi (Vitriani \& Budiasih, 2019). Kualitas laporan keuangan yang semakin tinggi menjelaskan keadaan perusahaan yang sesungguhnya sehingga memudahkan dalam mengambil keputusan investasi perusahaan agar efisien. Efisiensi investasi dapat dicapai jika manajer mengambil keputusan dengan tepat. Manajer dapat menentukan prinsip dalam pengambilan keputusan investasi yaitu konservatisme (Fransiska \& Triani, 2017). Selain itu, kebijakan dalam melakukan pendanaan yang tepat akan menyebabkan efisiensi investasi dapat tercapai (Fransiska \& Triani, 2017). Debt maturity adalah kebijkan perusahaan dalam menentukan jatuh tempo utang, baik short maturity atau long maturity (Rahmawati \& Harto, 2014). Hal ini sejalan dengan perusahaan akan dihadapkan dengan penentuan debt maturity pada saat memilih hutang sebagai sumber pendanaan.

Hal lain yang mempengaruhi efisiensi investasi yaitu Sustainability Reporting $(\mathrm{SR})$ atau laporan berkelanjutan. SR merupakan hal yang harus diperhatikan oleh perusahaan agar perusahaan memiliki citra yang baik dimata masyarakat. Hal ini dikarenakan kegiatan operasional yang dilakukan perusahaan sering berdampak pada lingkungan masarakat sekitar. Risiko litigas adalah faktor lain yang dapat mempengaruhi efisiensi investasi. Risiko litigasi yaitu risiko yang dimiliki perusahaan karena terjadi pelanggaran perjanjian yang dilakukan perusahaan sehingga adanya klaim dari pihak ketiga (Putri dkk., 2017). Risiko litigasi yang tinggi akan membuat manajer memberikan informasi yang menggambarkan kondisi perusahaan yang sesungguhnya kepada para pihak yang berkepentingan.

Perbedaan penelitian ini dengan penelitian sebelumnya yaitu menambahkan variabel konservatisme dan debt maturity sebagai variabel independen serta menambahkan variabel risiko litigasi sebagai variabel moderasi. Hal ini dikarenakan hasil penilitian yang tidak konsisten memungkinkan ada faktor lain yang dapat mempengaruhi efisiensi investasi. Selain itu, penggunaan sampel pada perusahaan manufaktur juga meruapakan perbedaan dengan penelitian sebelumnya. Alasan mengambil sampel perusahaan sektor manufaktur dikarenakan sektor manufaktur memiliki pengaruh yang besar terhadap perekonomian Indonesia. Serta dipihnya periode 2015-2020 karena pada tahun tersebut perusahaan sektor manufatur mengalami penurunan pendapatam hingga mempengaruhi efisiensi investasi perusahaan. 


\section{TINJAUAN LITERATUR DAN PERUMUSAN HIPOTESIS}

Teory agency adalah teori yang menjelaskan hubungan antara agent dan principal. Pihak prinsipal meyakini bahwa agent adalah pihak yang mampu mengelola perusahaan sehingga akan mengambil keputusan yang tepat serta dapat menguntungkan pihak principal (Jensen \& Meckling, 1976). Menurut Ghozali dan Chairiri (2007) perusahaan mempunyai keharusan untuk memiliki hubungan yang baik dengan para pemangku kepentingan, terutama para pemangku kepentingan yang memberikan sumber daya yang besar untuk keperluan operasional perusahaan. Oleh karena itu, teori stakeholder merupakan teori yang mendorong perusahaan untuk menyediakan informasi kepada para pemangku kepentingan.

Menurut Istanti (2013) teori kontijensi berkaitan dengan perusahaan sulit untuk memperkirakan peristiwa yang terjadi dimasa depan. Ketidakpastian lingkungan, tugas, struktur, dan kultur organisasi adalah hal yang sulit diprediksi oleh perusahaan. Ketidakpastian lingkungan memiliki pengaruh yang besar sehingga perusahaan sulit untuk mengendalikan hal tersebut. Menurut Brown dan Deegan (1998) teori legitimasi mengatakan selain memperhatikan hak-hak investor, organisasi harus memperhatikan juga hak-hak publik. Dasar dari teori legitimasi adalah perusahaan dan masyarakat disekitar lingkungan operasional perusahaan memiliki kontrak sosial dan menggunakan sumber ekonomi (Ghozali \& Chairiri, 2007). Teori legitimasi memberikan dorongan kepada perusahaan untuk meyakini bahwa masyarakat dapat menerima kinerja dan aktivitas perusahaan.

Dalam pengambilan keputusan ekonomi, kualitas pelaporan keuangan yang tinggi akan memberikan kemudahan kepada pihak manajemen dan investor. Hal ini dikarenakan semakin tinggi kualitas laporan keuangan tersebut, maka informasi yang disajikan akan semakain menggambarkan kondisi sesungguhnya yang terjadi pada perusahaan. Sehingga keputusan manajemen terkait investasi menjadi lebih efisien karena asimetri informasi semakin kecil. Hal ini sejalan dengan teori stakeholder yaitu memberikan dorongan kepada perusahaan untuk menyediakan informasi kepada seluruh pihak yang berkepentingan agar terciptanya hubungan yang baik antara perusahaan dan para investor. Hal tersebut sejalan dengan penelitian yang dilakukan dilakukan Vitriani dan Budiasih (2019), Biddle dkk. (2009), Chen dkk. (2011), Kangarlouei dkk. (2011) dan Biddle (2009), maka diturunkan hipotesis sebagai berikut:

\section{$\boldsymbol{H}_{\text {: }}$ Kualitas Laporan Keuangan Berpengaruh Positif Terhadap Efisiensi Investasi.}

Penelitian yang dilakukan Hu dkk. (2015) menyatakan bahwa koservatsime menyediakan fasilitas arus informasi antara pihak-pihak yang berkepentingan. Penerapan prinsip konservatisme membantu manajer untuk mengurangi mengambil keputusan yang tidak efisien termasuk investasi yang dilakukan perusahaan. Hal ini sejalan dengan teori agensi yang menyatakan bahwa pihak manajemen lebih mengetahui informasi yang menguntungkan atau tidak bagi perusahaan. Hal tersebut sejalan dengan penelitian García Lara dkk. (2016), Razzaq dkk. (2016), maka diturunkan hipotesis sebagai berikut:

\section{H:: Konservatisme Berpengaruh Positif Terhadap Efisiensi Investasi.}

Daam penelitian Childs dkk. (2005) berpendapat konflik keagenan antara kreditur dan perusahaan dapat berkurang karena utang jangka pendek memiliki fleksibilitas yang tinggi. Sejalan dengan teori agensi dimana menyelaraskan kepentingan principal dan agent agar hak dan kewajiban masing-masing pihak dapat terpenuhi dan dijalankan dengan baik. Ketika terjadi kasus overinvestment, debt maturity yang rendah dapat menurunkan tingkat investasi karena perusaahn memiliki kewajiban untuk mengembalikan pinjaman kepada kreditur. Sementara ketika terjadi kasus underinvestment, debt maturity dapat meningkatkan efisiensi investasi perusahaan karena merupakan sumber pendanaan untuk melakukan investasi pada proyek dengan NPV positif. Hal 
tersebut sejalan dengan penelitian Amrullah (2013), Sakti dan Septiani (2015), maka diturunkan hipotesis sebagai berikut:

\section{$\boldsymbol{H}_{3}$ : Debt Maturity Berpengaruh Positif Terhadap Efisiensi Investasi.}

Sustainability Reporting meningkatkan citra positif perusahaan dimata investor sehingga diyakini bahwa investasi yang dilakukan di perusahaan tersebut efisien. Hal ini didukung oleh teori legitimasi yang mendorong perusahaan untuk melaksanakan Sustainability Reporting untuk meningkatkan citra positif perusahaan dimata masyarakat dan investor. Penelitan yang dilakukan Zhong dan Gao (2017) menyatakan bahwa pengungkapan CSR berkontribusi terhadap meningkatnya efisiensi investasi. Penelitian Dhaliwal dkk. (2011) menyatakan bahwa perusahaan yang melaksanakan pengungkapan CSR dengan baik lebih banyak mengungkapkan informasi keuangan maupun non-keuangan dibanding perusahaan yang melakukan pengungkapan CSR yang rendah. Dari penjelasan tersebut, maka diturunkan hipotesis sebagai berikut:

\section{H: Sustainability Reporting Berpengaruh Positif Terhadap Efisiensi Investasi.}

Risiko litigasi dapat diatasi dengan perusahaan menyajikan laporan keuangan dengan kualitas yang tinggi. Penelitian Biddle dkk., (2009) menyatakan bahwa risiko litigasi dapat meningkatkan kualitas laporan keuangan dan menurunkan asimetri informasi sehingga investasi yang dilakukan semakin efisien. Foerster dkk. (2017) menyatakan bahwa laba saat ini dapat digunakan untuk memprediksi arus kas dimasa depan. Ketika perusahaan memiliki risiko litigasi yang tinggi, maka informasi yang terdapat didalam laporan keuangan menggambarkan kondisi perusahaan yang sesungguhkan sehingga memudahkan dalam pengambilan keputusan investasi. Hal ini sejalan dengan teori stakeholder yaitu memberikan dorongan kepada perusahaan untuk menyediakan informasi yang berguna bagi pihak-pihak yang berkepentingan agar memudahkan dalam megambil keputusan. Dari penjelasan tersebut, maka diturunkan hipotesis sebagai berikut:

\section{Hs: Risiko Litigasi Memperkuat Pengaruh Positif Kualitas Laporan Keuangan Terhadap Efisiensi Investasi.}

Risiko litigasi terjadi ketika pelanggaran perjanjian yang dilakukan oleh perusahaan yang dapat membuat pihak ketiga merasa dirugikan. Manajer akan berusahan untuk menghindari litigasi dikarenakan dapat memberikan dampak buruk bagi nama perusahaan. Myers (1977) berpendapat bahwa investasi dengan NPV positif dapat dibiayai dengan utang jangka pendek sehingga masalah underinvestment dapat teratasi. Teori agensi menyatakan bahwa pihak principal memberikan tanggung jawab kepada pihak agent dalam mengambil keputusan yang tepat untuk perusahaan. Hal ini dikarenakan pihak agent lebih mengetahui informasi yang menguntungkan bagi perusahaan.

Dalam hal ini, manajer berperan dalam menentukan jatuh tempo utang. Debt maturity dapat meningkatkan efisiensi investasi perusahaan karena merupakan sumber pendanaan untuk melakukan investasi pada proyek dengan NPV positif. Sehingga dengan risiko litigasi yang tinggi peminjam lebih cenderung memberikan pinjaman hutang jangka pendek yang dapat digunakan sebagai pendanaan untuk melakukan investasi yang efisien. Dari penjelasan tersebut, maka diturnukan hipotesis sebagai berikut:

H6: Risiko Litigasi Memperkuat Pengaruh Positif Debt Maturity Terhadap Efisiensi Investasi. 


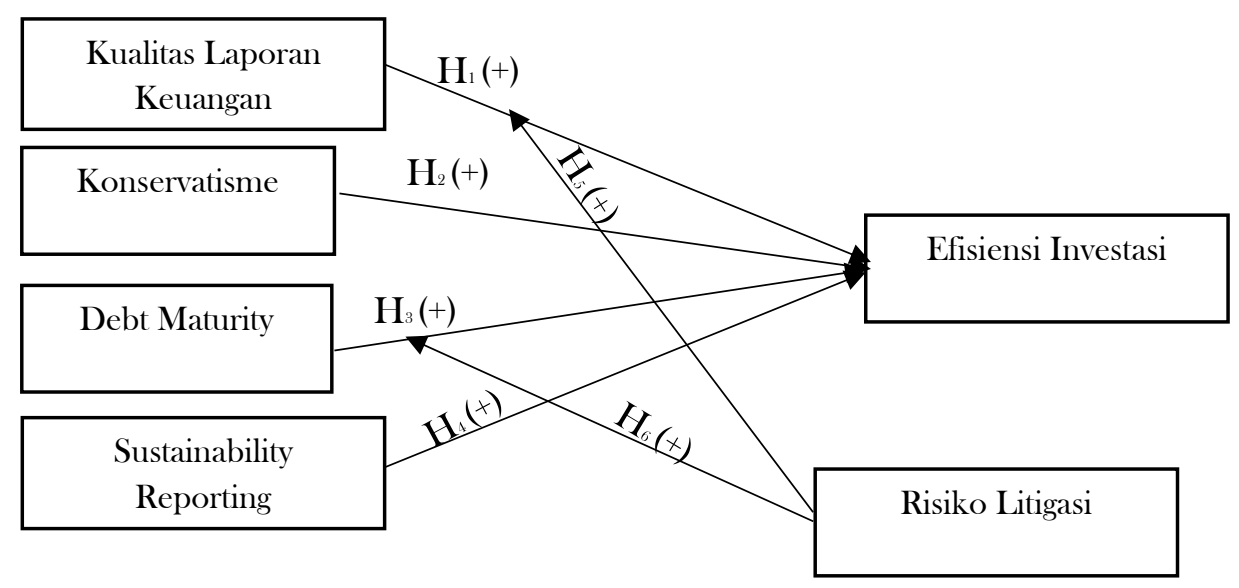

Gambar 1 Model Penelitian

\section{METODE PENELITIAN}

\section{Subjek Penelitian}

Populasi yaitu mengacu pada kesuluruhan kelompok, peristiwa, orang, atau sesuatu yang akan diteliti oleh peneliti. Populasi dalam penelitian ini adalah perusahaan manufatur yang telah terdaftar di Bursa Efek Indonesia (BEI) periode 2015-2020. Sampel adalah sebagian atau wakil dari populasi yang akan diteliti. Sampel yang akan digunakan dalam penelitian ini yaitu perusahaan manufaktur yang terdaftar di BEI periode 2015-2020 yang mempublikasikan annual reporting dan sustainability reporting.

\section{Teknik Pengambilan Sampel}

Purposive sampling adalah teknik pengambilan sampel yang digunakan dalam penelitian ini. Purposive sampling adalah proses pengambilan sampel yang disesuaikan dengan kriteria yang telah ditentukan oleh peneliti untuk membatasi jumlah sampel. Adapun kirteria sampel yang telah ditentukan dalam penelitian ini yaitu:

1. Perusahaan manufaktur yang terdaftar di Bursa Efek Indonesia yang mempublikasikan annual reporting dan sustainability reporting pada tahun 2015-2020 dan dapat diakses melalui website resmi perusahaan atau IDX.

2. Perusahaan yang tidak delisting pada periode penelitian 2015-2020.

\section{Jenis Data}

Data kuantitatif adalah jenis data yang digunakan dalam penelitian ini. Penelitian kuantitatif menggunakan data sekunder dimana data tersebut merupakan data yang diperoleh dari annual reporting dan sustainability reporting perusahaan manufaktur yang terdaftar di BEI dari tahun 20152020. Data tersebut diakses dari situs www.idx.co.id dan situs resmi perusahaan. Kemudian data tersebut dianalisis lebih lanjut dalam tahap analisis data.

\section{Teknik Pengumpulan Data}

Teknik pengumpulan data yang digunakan dalam penelitian ini adalah teknik pengumpulan data dokumentasi yaitu menggunakan data sekunder dari annual reporting dan sustainability reporting perusahaan manufaktur yang terdaftar di Bursa Efek Indonesia periode 2015-2020. Penelitian ini juga memiliki sumber lain yang diperoleh dengan mempelajari beberapa jurnal atau artikel yang berkaitan dengan penelitian ini. 


\section{Teknik Analisis Data}

Analisis data dalam penelitian ini menggunakan software SPSS 21.0. Dalam penelitian ini, uji untuk $\mathrm{H}_{1}, \mathrm{H}_{2}, \mathrm{H}_{3}$, dan $\mathrm{H}_{4}$ menggunakan analisis regresi linear berganda sementara $\mathrm{H}_{5}$ dan $\mathrm{H}_{6}$ menggunakan Moderated Regresion Analysis (MRA). Model regersi berganda dari penelitian ini adalah sebagai berikut:

$$
\begin{aligned}
& \mathrm{Y}=\alpha+\beta_{1} \mathrm{KLK}+ \beta_{2} \mathrm{KONS}+\beta_{3} \text { DEBTMAT }+\beta_{4} \mathrm{SR}+e \\
& \mathrm{Y}=\alpha+\beta_{1} \mathrm{KLK}+\beta_{2} \mathrm{KONS}+\beta_{3} \mathrm{DEBTMAT}+\beta_{4} \mathrm{SR}+\beta_{5} \mathrm{RL}+\beta_{6} \mathrm{KLK}^{*} \mathrm{RL}+ \\
& \beta_{7} \mathrm{DEBTMAT}^{*} \mathrm{RL}+e
\end{aligned}
$$

Keterangan: $\mathrm{Y}=$ Efisiensi Investasi; $\alpha=$ Konstanta; $\beta=$ Koefisien Regresi; KLK = Kualitas Laporan Keuangan; KONS = Konservatisme; DEBTMAT $=$ Debt Maturity; SR = Sustainability Reporting ; $\mathrm{RL}=$ Risiko Litigasi; $e=$ Standard error

\section{HASIL DAN PEMBAHASAN}

Tabel 1 Data Sampel Penelitian

\begin{tabular}{clc}
\hline No & \multicolumn{1}{c}{ Keterangan } & Jumlah \\
\hline 1 & $\begin{array}{l}\text { Perusahaan manufaktur yang menerbitkan annual report dan sustainability } \\
\text { reporting tahun 2015 }\end{array}$ & 10 \\
2 & $\begin{array}{l}\text { Perusahaan manufaktur yang menerbitkan annual report dan sustainability } \\
\text { reporting tahun 2016 }\end{array}$ & 12 \\
3 & $\begin{array}{l}\text { Perusahaan manufaktur yang menerbitkan annual report dan sustainability } \\
\text { reporting tahun 2017 }\end{array}$ & 14 \\
4 & $\begin{array}{l}\text { Perusahaan manufaktur yang menerbitkan annual report dan sustainability } \\
\text { reporting tahun 2018 }\end{array}$ & 18 \\
5 & $\begin{array}{l}\text { Perusahaan manufaktur yang menerbitkan annual report dan sustainability } \\
\text { reporting tahun } 71\end{array}$ & 17 \\
6 & $\begin{array}{l}\text { Perusahaan manufatur yang menerbitkan annual report dan sustainability } \\
\text { reporting tahun 2020 }\end{array}$ & 16 \\
7 & Perusahaan manufatur yang delisting selama tahun 2015-2020 & $(0)$ \\
\hline Jumlah & & 87 \\
\hline
\end{tabular}

Berdasarkan data yang diperoleh dari www.idx.co.id, populasi dalam penelitian ini berjumlah 142 perusahaan. Jumlah sampel dalam penelitian ini adalah 87 dengan metode purposive sampling yang digunakan sebagai metode pemilihan sampel.

Tabel 2 Uji Statistik Deskriptif

\begin{tabular}{llccccc}
\hline & N & Minimum & Maximum & Mean & Median & Std. Deviation \\
\hline KLK & 87 & $-17,2347$ & $-0,0528$ & $-2,7197$ & $-0,9969$ & 2,6128 \\
Konservatisme & 87 & $-0,2876$ & 0,2076 & $-0,0329$ & $-0,0143$ & 0,0724 \\
Debt Maturity & 87 & 0,3654 & 0,9540 & 0,7348 & 0,8954 & 0,2687 \\
SR & 87 & 0,2278 & 0,4678 & 0,3762 & 0,3472 & 0,0824 \\
Efisiensi Investasi & 87 & $-0,2206$ & 0,3291 & 0,2743 & 0,9564 & 0,8162 \\
Risiko Litigasi & 87 & 0,2499 & 2,2654 & 1,0439 & 0,0156 & 0,8267 \\
Valid N (listwise) & 87 & & & & & \\
\hline
\end{tabular}

Berdasarkan Tabel hasil uji statistik deskriptif di atas maka dapat disimpulkan bahwa data sampel berjumlah 87 sampel yang merupakan annual reporting dan sustainability reporting perusahaan manufaktur yang terdaftar di BEI periode 2015-2020. 


\section{Hasil Pengujian Hipotesis}

Sebelum melakukan uji hipotesis, dilakukan uji asumsi klasik yang terdiri dari uji normalitas, uji autokorelasi, uji multikolinearitas dan uji heteroskedastisitas. Dari hasil uji asumsi klasi yang telah dilakukan didapatkan bahwa data dalam penelitian ini telah memenuhi persyaratan uji asumsi klasik sehingga dapat dilanjutkan untuk uji analisis regresi linear berganda.

Tabel 3 Uji Koefisien Determinasi Model Persamaan 1

\begin{tabular}{ccccc}
\hline Model & R & R Square & Adjusted R Square & Std. Error of the Estimate \\
\hline 1 &, 649 &, 421 &, 367 &, 051159 \\
\hline
\end{tabular}

Berdasarkan Tabel 3, menunjukkan besarnya koefisien determinasi $\left(\right.$ Adjusted $\left.R^{2}\right)=0,367$, artinya variabel independen Kualitas Laporan Keuangan, Konservatisme, Debt Maturity, dan Sustainability Reporting mampu menjelaskan variabel dependen Efesiensi Investasi sebesar 36,7\%. Sementara sisanya sebesar $63,3 \%$ dipengaruhi oleh variabel lain yang tidak dimasukkan dalam model penelitian.

Tabel 4 Uji Koefisien Determinasi Model Persamaan 2

\begin{tabular}{ccccc}
\hline Model & R & R Square & Adjusted R Square & Std. Error of the Estimate \\
\hline 1 &, 706 &, 498 &, 410 &, 04978 \\
\hline
\end{tabular}

Berdasarkan Tabel 4, menunjukkan besarnya koefisien determinasi $\left(\right.$ Adjusted $\left.R^{p}\right)=0,410$, artinya variabel Kualitas Laporan Keuangan, Konservatisme, Debt Maturity, Sustainability Reporting; interaksi Kualitas Laporan Keuangan dengan Risiko Litigasi, dan interaksi Debt Maturity dengan Risiko Litigasi mampu menjelaskan variabel Efisiensi Investasi sebesar 41\%. Sementara sisanya sebesar $59 \%$ dipengaruhi oleh variabel lain yang tidak dimasukkan dalam model penelitian.

Tabel 5 Uji Simultan Model Persamaan 1

\begin{tabular}{llccccc}
\hline & Model & Sum of Squares & df & Mean Squares & F & Sig. \\
\hline 1 & Regression &, 083 & 3 &, 021 & 7,803 &, 000 \\
Residual &, 114 & 43 &, 003 & & \\
Total &, 197 & 47 & & & \\
& & & & & & \\
\end{tabular}

Dari hasil uji F pada Tabel 5 diperoleh $\boldsymbol{F}$ hitung sebesar 7,803 dan sig sebesar 0,000. Karena nilai sig $\mathbf{F}<\alpha 0,05(0,000<\alpha 0,05)$, dapat disimpulkan bahwa variabel independen Kualitas Laporan Keuangan, Koservatisme, Debt Maturity dan Sustainability Reporting secara bersamasama berpengaruh terhadap Efisiensi Investasi.

Tabel 6 Uji Simultan Model Persamaan 2

\begin{tabular}{llccccc}
\hline & Model & Sum of Squares & df & Mean Squares & F & Sig. \\
\hline 1 & Regression &, 098 & 7 &, 014 & 5,673 &, 000 \\
& Residual &, 099 & 40 &, 002 & & \\
& Total &, 197 & 47 & & & \\
\hline
\end{tabular}

Dari hasil uji F pada Tabel 6 diperoleh $F$ hitung sebesar 5,673 dan sig sebesar 0,000. Karena nilai sig $\mathbf{F}<\alpha 0,05(0,000<\alpha 0,05)$, dapat disimpulkan bahwa Kualitas Laporan Keuangan, Koservatisme, Debt Maturity, Sustainability Reporting, KLK ${ }^{*} \mathrm{RL}$ dan DM*RL secara bersamasama berpengaruh terhadap Efisiensi Investasi. 
Tabel 7 Uji Parsial Model Persamaan 1

\begin{tabular}{|c|c|c|c|c|c|c|}
\hline & Model & Undstanc & Joefficients & Standardized Coefficients & $\mathrm{t}$ & Sig. \\
\hline & & B & Std. Error & Beta & & \\
\hline 1 & (Constant) & ,127 & ,046 & & 2,746 & 009 \\
\hline & Kualitas & 034 & 016 & 271 & 2,100 & 042 \\
\hline & Laporan & & & & & \\
\hline & Keuangan & & & & & \\
\hline & Konservatisme & ,394 & ,0195 &, 270 & 2,024 & ,049 \\
\hline & Debt Maturity & 074 & ,026 & 379 & 2,880 & ,006 \\
\hline & Sustainability & 044 & ,027 & ,210 & 1,676 & 101 \\
\hline & Reporting & & & & & \\
\hline
\end{tabular}

Tabel 8 Uji Parsial Model Persamaan 2

\begin{tabular}{|c|c|c|c|c|c|c|}
\hline & Model & Undstar & d Coefficients & Standardized Coefficients & $\mathrm{t}$ & Sig. \\
\hline & & B & Std. Error & Beta & & \\
\hline 1 & (Constant) & ,088 & ,048 & & 1,849 & ,072 \\
\hline & $\begin{array}{l}\text { Kualitas Laporan } \\
\text { Keuangan }\end{array}$ & ,036 & 016 & 288 & 2,309 & ,026 \\
\hline & Konservatisme & 394 & 194 & ,271 & 2,035 & ,049 \\
\hline & Debt Maturity & 065 & 025 & 333 & 2,570 & 014 \\
\hline & Sustainability & ,020 & ,08 & ,096 &, 742 & ,463 \\
\hline & Reporting & & & & & \\
\hline & Risiko Litigasi & 015 & 014 & ,209 & 1,076 & 289 \\
\hline & $\mathrm{KLK}^{*} \mathrm{RL}$ & ,027 & ,012 & 354 & 2,242 & ,031 \\
\hline & $\mathrm{DM}^{*} \mathrm{RL}$ &,- 012 & ,020 &,- 095 &,- 596 &, 042 \\
\hline
\end{tabular}

\section{Pengaruh Kualitas Laporan Keuangan Terhadap Efisiensi Investasi}

Hasil penelitian ini menunjukkan bahwa Kualitas Laporan Keuangan berpengaruh positif terhadap Efisiensi Investasi. Berdasarkan perspektif teori stakeholder, dengan meningkatkan kualitas pelaporan keuangan dapat mengurangi asimetri informasi. Masalah overinvestment dan underinvestmet yang dihadapi perusahaan juga dapat berkurang dengan meningkatkan kualitas pelaporan keuangan. Selain itu, kualitas pelaporan keuangan juga dapat meningkatkan efisiensi investasi karena memungkinkan manajer untuk mengetahui investasi yang memiliki peluang untuk menguntungkan perusahaan sehingga dapat mengambil keputusan investasi yang baik (Juliani \& Wardhani, 2018).

Hal ini sejalan dengan penelitian yang dilakukan oleh Rahmawati dan Harto (2014) yang menyatakan bahwa kualitas pelaporan keuangan mengurangi sensitivitas arus kas investasi. Dengan meningkatnya kualitas pelaporan keuangan serta menurunnya masalah asimetri informasi dapat menciptakan efisiensi investasi bagi perusahaan atau dengan kata lain investasi yang dilakukan oleh perusahaan berjalan secara efisien karena sesuai dengan investasi yang diharapkan.

\section{Pengaruh Konservatisme Terhadap Efisiensi Investasi}

Hasil penelitian ini menunjukkan bahwa Koservatisme berpengaruh positif terhadap Efisiensi Investasi. Penelitian yang dilakukan Hu dkk. (2015) menyatakan bahwa koservatsime menyediakan fasilitas arus informasi antara pihak-pihak yang berkepentingan. Penerapan prinsip konservatisme membantu manajer untuk mengurangi kemungkinan mengambil keputusan yang tidak efisien termasuk terkait dengan investasi yang dilakukan perusahaan. Hal ini sejalan dengan teori agensi dimana pihak manajemen lebih mengetahui informasi-informasi yang menguntungkan atau tidak bagi perusahaan. Dengan penerapan konservatisme, perusahaan dapat mengontrol manajer agar bertindak sesuai dengan kepentingan para stakeholder.

Perusahaan yang konservarif dalam mengelola investasinya akan cenderung lebih efisien. Dimana perusahaan yang konservatif akan lebih cepat merespon bad news dan kerugian yang akan terjadi dimasa depan lebih cepat diketahui. Selain itu, konservastisme memiliki peran penting pada laporan keuangan perusahaan yang digunakan sebagai dasar mengambil keputusan terkait investasi. 
Hal ini menyebabkan manajer akan lebih berhati-hati dalam mengambil keputusan investasi agar terciptanya efisiensi investasi.

\section{Pengaruh Debt Maturity Terhadap Efisiensi Investasi}

Hasil penelitian ini menunjukkan bahwa Debt Maturity berpengaruh positif terhadap Efisiensi Investasi. Debt maturity dapat digunakan untuk mengurangi masalah overinvestment dan underinvestment. Dalam hal ini, kreditur dapat memonitor peminjam dengan lebih baik dan dapat mengurangi konflik keagenan yang muncul dari peluang investasi yang disebabkan utang jangka pendek terus berputar. Hal ini berdasarkan teori agensi yang menjelaskan antara hubungan agent dan principal dimana pihak principal mengawasi pihak agent agar tetap menjalankan perusahaan sesuai dengan tujuan yang telah ditetapkan oleh perusahaan tersebut. Dengan demikian, masalah overinvestment dan underinvestment dapat dikurangi sehingga investasi yang dilakukan perusahaan berjalan secara efisien.

Hal ini sejalan dengan penelitian Sakti dan Septiani (2015) yang menyatakan bahwa utang jangka pendek berperan dalam meningkatkan efisiensi investasi. Penyimpangan investasi dapat berkurang dan efisiensi investasi dapat meningkat dikarenakan keberadaan utang jangka pendek sehingga kreditur mengawasi manajer dengan lebih baik. Pengawasan yang dilakukan oleh kreditur dapat mengurangi konflik keagenan antara kreditur dan peminjam dikarenakan memiliki hubungan yang lebih dekat untuk menetapkan suku bunga dan memastikan kinerja perusahaan pada awal periode (Cutillas Gomariz \& Sánchez Ballesta, 2013).

\section{Pengaruh Sustainability Reporting Terhadap Efisiensi Investasi}

Hasil penelitian ini menunjukkan bahwa Sustainability Reporting tidak berpengaruh terhadap Efisiensi Investasi. Berdasarkan teori legitimasi Sustainability Reporting merupakan cara perusahaan untuk mendapatkan penilaian yang positif dari masyarakat atau investor. Hasil penelitian ini bertentangan dengan teori legitimasi, yang menyatakan bahwa SR adalah cara perusahaan agar mendapatkan citra yang positif dari masyarakat atau investor. Hasil penelitian ini sejalan dengan penelitian Vitriani dan Budiasih (2019) yang dalam penelitiannya menyatakan bahwa Sustainability Reporting tidak berpengaruh terhadap efisiensi investasi. Dimana hal ini menandakan bahwa pada perusahaan manufaktur yang terdaftar di BEI tahun 2015-2019, pengungkapan SR tidak mempengaruhi citra positif perusahaan kepada investor sehingga tidak berpengaruh terhadap efisiensi invetasi perusahaan. Hal ini mungkin dikarenakan investor atau calon investor belum terlalu mengerti dan memahami penggunaan SR untuk mengambil keputusan berinvestasi (Vitriani \& Budiasih, 2019).

\section{Risiko Litigasi Memperkuat Pengaruh Positif Antara Kualitas Laporan Keuangan Terhadap Efisiensi Investasi}

Hasil penelitian ini menunjukkan bahwa Risiko Litigasi memperkuat pengaruh positif Kualitas Laporan Keuangan terhadap Efisiensi Investasi. Risiko litigasi merupakan risiko yang berpotensi menimbulkan biaya yang tidak sedikit karena berurusan dengan masalah hukum. Sehingga untuk menghindari risiko litigasi yang tinggi perusahaan meningkatkan kualitas laporan keuangan. Laporan keuangan yang diterbitkan menggambarkan kondisi perusahaan sebenarnya sehingga memudahkan investor dalam mengambil keputusan investasi sehingga invetasi yang dilakukan berjalan secara efisien. Hal ini sesuai dengan teori stakeholder yang mendorong perusahaan untuk memberikan informasi kepada pihak yang berkepentingan yaitu menerbitkan laporan keuangan.

Hal ini sejalan dengan penelitian yang dilakukan oleh Cahyaningtyas dkk. (2019) yang menyatakan bahwa risiko litigasi yang dimiliki perusahaan akan semakin meningkat bersamaan dengan meningkatnya penegakan hukum (law ecforcement) dalam lingkungan perusahaan modal. Ketidakpatuhan terhadap standar akuntansi dan melakukan penundaan dalam menyajikan informasi yang negatif merupakan bahan tuntutan karena laporan keuangan yang tidak sesuai dengan peraturan yang berlaku dapat menyebabkan adanya tuntutan hukum terhadap perusahaan. 


\section{Risiko Litigasi Memperkuat Pengaruh Positif Antara Debt Maturity Terhadap Efisiensi Investasi}

Hasil penelitian ini menunjukkan bahwa Risiko Litigasi memperkuat pengaruh positif Debt Maturity terhadap Efisiensi Investasi. Hasil penelitian ini sejalan dengan penelitian Malm dan Krolikowski (2017) yang menyatakan bahwa risiko litigasi menimbulkan konsekuensi reputasi yang buruk terhadap perusahaan. Teori agensi menyatakan bahwa pihak principalmemberikan tanggung jawab kepada pihak agent dalam mengambil keputusan yang tepat untuk perusahaan. Hal ini dikarenakan pihak agent lebih mengetahui informasi yang menguntungkan bagi perusahaan. Dalam penelitian ini sesuai dengan teori agensi yaitu adanya risiko litigasi dalam perusahaan mempengaruhi kepercayaan kreditur kepada perusahaan.

Dimana ketika risiko litigasi perusahaan tinggi maka akan mempengaruhi kepercayaan kreditur dalam memberikan pinjaman jangka pendek. Sehingga hal tersebut akan mempengaruhi sumber pendanaan untuk melakukan investasi. Ketika perusahaan mengalami kekurangan dana maka akan berakibat underinvestment sehingga investasi perusahaan tidak efisien. Ketika risiko litigasi tinggi, kreditur melakukan pengawasan yang ketat dengan mengenakan bunga yang tinggi dan memperketat persyaratan peminjaman.

\section{KESIMPULAN}

Penelitian ini bertujuan untuk menguji pengaruh Kualitas Laporan Keuangan, Konservatisme, Debt Maturity, Sustainability Reporting, Kualitas Laporan Keuangan yang dimoderasi Risiko Litgasi, dan Debt Maturity yang dimoderasi Risiko Litigasi terhadap Efisiensi Invetsasi. Berdasarkan hasil uji hipotesis yang dilakukan peneliti, dapat ditarik kesimpulan sebagai berikut. (1) Kualitas Laporan Keuangan berpengaruh positif terhadap Efisiensi Investasi. (2) Koservatisme berpengaruh positif terhadap Efisiensi Investasi. (3) Debt Maturity berpengaruh positif terhadap Efisiensi Investasi. (4) Sustainability Reporting tidak berpengaruh terhadap Efisiensi Investasi. (5) Risiko Litigasi memperkuat pengaruh positif antara Kualitas Laporan Keuangan terhadap Efisiensi Investasi. (6) Risiko Litigasi memperkuat pengaruh positif Debt Maturity terhadap Efisiensi Investasi.

Penelitian ini memiliki keterbatasan dimana sampel penelitian hanya berfokus kepada perusahaan sector manufaktur saja. Untuk penelitian selanjutnya disarankan untuk melakukan penelitian tentang Efisiensi Investasi pada sector industri lain seperti, pertambangan, properti, kosntruksi, dan lain-lain. Sehingga hasil penelitian yang didapatkan memiliki cakupan yang luas. Penelitian ini hanya menguji pengaruh Kualitas Laporan Keuangan, Konservatisme, Debt Maturity , dan Sustainability Reporting terhadap Efisiensi Investasi. Penelitian selanjutnya disarankan dapat menambahkan variabel lain seperti asimetri informasi, kepemilikan manajerial, ukuran perusahaan, dan berbagai variabel lainnya yang mempengaruhi Efisiesni Investasi. Penelitian selanjutnya disaranakan menggunakan proksi yang lain dalam mengukur variabel independen, variabel dependen maupun variabel moderasi untuk mendapatkan hasil yang lebih baik lagi.

\section{DAFTAR PUSTAKA}

Amrullah, Z. (2013). Pengaruh Kualitas Laporan Keuangan dan Debt Maturity Terhadap Efisiensi Investasi Perusahaan di Indonesia. Skripsi. Univeristas Indonesia.

Ardana, I. G. P. S., \& Sujana, I. K. (2018). Risiko Litigasi sebagai Variabel Pemoderasi Pengaruh Kualitas Laporan Keuangan pada Efisiensi Investasi. E-Jurnal Akuntansi Universitas Udayana. 2(2), 1389-1418. https://doi.org/10.24843/EJA.2018.v22.i02.p21

Biddle, G. C., Hilary, G., \& Verdi, R. S. (2009). How does financial reporting quality relate to investment efficiency? Journal of Accounting and Economics, 48(2-3), 112-131. https://doi.org/10.1016/j.jacceco.2009.09.001 
Brown, N., \& Deegan, C. (1998). The public disclosure of environmental performance information-a dual test of media agenda setting theory and legitimacy theory. Accounting and Business Research, 29(1), 21-41. https://doi.org/10.1080/00014788.1998.9729564

Cahyaningtyas, S. R., Husnaini, W., \& Isnaini, Z. (2019). Kualitas Pelaporan Keuangan, Hutang Jangka Pendek dan Efisiensi Investasi. Jurnal Riset Akuntansi Aksioma. 18(1), 57-83. https://doi.org/10.29303/aksioma.v18i1.54

Chen, F., Hope, O.-K., Li, Q., \& Wang, X. (2011). Financial Reporting Quality and Investment Efficiency of Private Firms in Emerging Markets. The Accounting Review, 86(4), 1255-1288. https://doi.org/10.2308/accr-10040

Childs, P. D., Mauer, D. C., \& Ott, S. H. (2005). Interactions of corporate financing and investment decisions: The effects of agency conflicts. Journal of Financial Economics, 76(3), 667-690. https://doi.org/10.1016/j.jfineco.2004.06.012

Cutillas Gomariz, M. F., \& Sánchez Ballesta, J. P. (2014). Financial reporting quality, debt maturity and investment efficiency. Journal of Banking \& Finance, 40, 494-506. https://doi.org/10.1016/j.jbankfin.2013.07.013

Dhaliwal, D. S., Li, O. Z., Tsang, A., \& Yang, Y. G. (2011). Voluntary Nonfinancial Disclosure and the Cost of Equity Capital: The Initiation of Corporate Social Responsibility Reporting. The Accounting Review, 86(1), 59-100. https://doi.org/10.2308/accr.00000005

Foerster, S., Tsagarelis, J., \& Wang, G. (2017). Are Cash Flows Better Stock Return Predictors Than Profits? Financial Analysts.Journal, 73(1), 73-99. https://doi.org/10.2469/faj.v73.n1.2

Fransiska, E., \& Triani, N. N. A. (2017). Pengaruh Konservatisme Akuntansi dan Maturity Terhadap Efisiensi Investasi. Jurnal Akuntansi Dan Bisnis. 53(9), 1689-1699. Diakses dari https://jurnalmahasiswa.unesa.ac.id/index.php/jurnal-akuntansi/article/view/29117

García Lara, J. M., García Osma, B., \& Penalva, F. (2016). Accounting conservatism and firm investment efficiency. Journal of Accounting and Economics, 61(1), 221-238. https://doi.org/10.1016/j.jacceco.2015.07.003

Ghozali, I., \& Chairiri, A. (2007). Teori Akuntansi: 4. Semarang: Badan Penerbit Univeristas Diponegoro.

Hu, J., Li, A. Y., \& Zhang, F. (Frank). (2014). Does accounting conservatism improve the corporate information environment? Journal of International Accounting, Auditing and Taxation, 23(1), 32-43. https://doi.org/10.1016/j.intaccaudtax.2014.02.003

Istanti, S. L. W. (2013). Teori Kontingensi, Sistem Pengendalian Manajemen dan Keluaran Perusahaan: Hasil Yang Lalu Dan Arah Masa Depan. Potensio, 18(2), 94-99.

Jensen, M. C., \& Meckling, W. H. (1976). Theory of the firm: Managerial behavior, agency costs and ownership structure. Journal of Financial Economics, 3(4), 305-360. https://doi.org/10.1016/0304-405x(76)90026-x

Juliani, D., \& Wardhani, R. (2018). Pengaruh Konservatisme Terhadap Efisiensi Investasi dan Agency Cost Sebagai Variabel Moderasi Pada Perusahaan Yang Melakukan Merger Dan Akuisisi di Asia Tenggara. Jurnal Akuntansi, 22(2), 266. https://doi.org/10.24912/ja.v22i2.352

Kangarlouei, S. J., Motavassel, M., Azizi, A., \& Farahani, M. S. (2011). The Investigation of The Relationship Between Financial Reporting Quality and Investment Efficiency in Tehran Stock Exchange (TSE). Australian Journal of Basic and Applied Sciences, 5(12), 1165-1172.

Malm, J., \& Krolikowski, M. (2015). Litigation risk and financial leverage. Journal of Economics and Finance, 41(1), 180-194. https://doi.org/10.1007/s12197-015-9348-0

Myers, S. C. (1977). Determinants of corporate borrowing. Journal of Financial Economics, 5(2), 147-175. https://doi.org/10.1016/0304-405x(77)90015-0

Putri, A. G., Darlis, E., \& Anggraini, L. (2017). Pengaruh Kesulitan Keuangan, Risiko Litigasi, Dan Leverage Terhadap Konservatisme Akuntansi Pada Perusahaan Dagang Yang Terdaftar Di Bursa Efek Indonesia (2012-2014). Jurnal Online Mahasiswa Fakultas Ekonomi Universitas Riau, 4(1), 1337-1350. Diakses dari https://jom.unri.ac.id/index.php/JOMFEKON/article/view/12816 
Rahmawati, A. D., \& Harto, P. (2014). Analisis pengaruh kualitas pelaporan keuangan dan maturitas utang terhadap efisiensi investasi. Diponegoro Journal of Accounting, 71-82. Diakses dari https://ejournal3.undip.ac.id/index.php/accounting/article/view/6043

Razzaq, N., Zhang, R., \& Donghua, Z. (2016). Accounting Conservatism Alleviates Firm's Investment Efficiency: An Evidence from China. International Journal of Business and Economics Research, 5(4), 85. https://doi.org/10.11648/j.ijber.20160504.12

Sakti, A. M., \& Septiani, A. (2015). Pengaruh kualitas pelaporan keuangan dan jatuh tempo utang terhadap efisiensi investasi. Diponegoro Journal of Accounting, 4(2), 792-801. Diakses dari https://ejournal3.undip.ac.id/index.php/accounting/article/view/16523

Vitriani, N., \& Budiasih, I. (2019). Pengaruh Kualitas Pelaporan Keuangan Dan Sustainability Reporting Pada Efisiensi Investasi. E-Jurnal Akuntansi, 28(1), 188 - 213. https://doi.org/10.24843/eja.2019.v28.i01.p08

Zhong, M., \& Gao, L. (2017). Does corporate social responsibility disclosure improve firm investment efficiency? Review of Accounting and Finance, 16(3), 348-365. https://doi.org/10.1108/raf-06-2016-0095 